\title{
Association between disc displacement without reduction and temporomandibular joint derangement observed on magnetic resonance imaging
}

\author{
- Juliane Piragine Araujo Department of Stomatology, School of Dentistry, University of São Paulo, São Paulo, \\ Brazil • Marcelo Eduardo Pereira Dutra School of Dentistry, Nove de Julho University, São Paulo, Brazil • Karina Cecília \\ Panelli Santos Private Practitioner
}

ABSTRACT | This study aimed to assess possible associations between the following factors: articular disc anatomy and position; articular eminence and condyle morphology; presence of joint effusion; condyle mobility; and lateral pterygoid muscle insertion pattern. Magnetic resonance images of 33 joints of symptomatic patients were assessed. The articular disc was classified as normal, elongated, or folded; displacement was classified as normal, lateral, or medial; the condyle was classified as rounded, convex, flattened, or angulated; the articular eminence was classified as box, sigmoid, flattened, or deformed; condyle mobility was classified as normal, hypomobile, or hypermobile; and the lateral pterygoid muscle insertion pattern was classified as Type I, Type II, or Type III. The most frequent forms of articular disc, articular eminence, and condyle were folded, flattened, and flattened, respectively. There can be a relationship connecting TMJ mobility with a normal disc form (100\%); TMJ hypomobility with a folded disc form (48\%); and TMJ hypermobility with an elongated disc form (100\%). Magnetic resonance imaging allowed the clear observation of articular structures, and no association was found between insertion pattern and sideways disc position, disc form, and condyle form. All cases with joint effusion were related to hypomobility (100\%).

DESCRIPTORS | Pterygoid Muscles; Temporomandibular Joint; Temporomandibular Joint Disc; Mandibular Condyle; Magnetic Resonance Imaging.

RESUMO | Associação entre o deslocamento de disco sem redução com desarranjos internos da articulação temporomandibular observados na imagem por ressonância magnética • O objetivo deste estudo foi avaliar possíveis associações entre os seguintes fatores: anatomia e posição do disco articular; morfologia da eminência articular e da cabeça da mandíbula; presença de derrame articular; mobilidade da cabeça da mandíbula; e inserção do músculo pterigoideo lateral. Foram avaliadas imagens de ressonância magnética de 33 articulações de pacientes sintomáticos. O disco articular foi classificado como normal, alongado ou dobrado; o deslocamento foi classificado como normal, lateral ou medial; a cabeça da mandíbula foi classificado como arredondado, convexo, achatado ou angulado; a eminência articular foi classificada como caixa, sigmoide, achatada ou deformada; a mobilidade da cabeça da mandíbula foi classificada como normal, hipomobilidade ou hipermobilidade; e o padrão de inserção do músculo pterigoideo lateral foi classificado como Tipo I, Tipo II ou Tipo III. As formas mais frequentes do disco articular, eminência articular e cabeça da mandíbula foram dobrado, achatada e achatado, respectivamente. Pode existir uma relação da mobilidade da ATM que tende a apresentar uma forma de disco normal (100\%), hipomobilidade da ATM com forma do disco dobrado (48\%); e hipermobilidade da ATM com forma de disco alongado (100\%). A ressonância magnética permitiu a observação clara das estruturas articulares e não foi encontrada associação entre o padrão de inserção e a posição lateral do disco, a forma do disco e a forma da cabeça da mandíbula. Todos os casos em que o derrame articular estava presente estavam relacionados à hipomobilidade (100\%).

DESCRITORES | Músculos Pterigoides; Articulação Temporomandibular; Disco da Articulação Temporomandibular; Cabeça da Mandíbula; Imagem por Ressonância Magnética.

CORRESPONDING AUTHOR | • Juliane Piragine Araujo Department of Stomatology, School of Dentistry, University of São Paulo • Av. Professor Lineu Prestes, 2227, Cidade Universitária São Paulo, SP. Brazil • 05508-000 Email: jupiragine@usp.br

- Received Aug 27, 2015 • Accepted Oct 03, 2015

- Dol http://dx.doi.org/10.11606/issn.2357-8041.clrd.2015.127551 


\section{INTRODUCTION}

The temporomandibular joint (TMJ) is located on both sides of the head, where the mandibular fossa of the temporal bone and the mandibular condyle articulate. ${ }^{1}$ Although the lateral pterygoid muscle (LPM) has been extensively studied in recent years, its anatomic and physiological functions are not entirely understood. One possible reason is because most studies on this muscle have been done on cadavers. ${ }^{2}$ LPM is a muscle with two separate heads: the superior head originates from the infratemporal surface of the greater wing of the sphenoid bone and from the infratemporal crest, while the inferior head stems from the lateral surface of the lateral pterygoid plate. The former attaches to the anteromedial surface of the TMJ disc and to the condylar neck, and the latter enters the pterygoid fossa lateroposteriorly on the anteromedial condylar surface. ${ }^{3}$

TMJ derangement is related to any disturbance that affects joint function, and is frequently associated to the articular disc, bone structures, and joint effusion. ${ }^{4}$ The advantages of magnetic resonance imaging (MRI) regarding TMJ evaluation are well established: it is a radiation-free technique that can effectively show TMJ changes in bones and soft tissue structures. ${ }^{5}$ Studies are unanimous on the utility of MRI to analyze changes in the articular disc, articular eminence, and joint effusion. ${ }^{4,6}$

This study aimed to use MRI to investigate any possible associations between disc displacement without reduction, TMJ derangement, condyle mobility, and LPM superior head insertion pattern.

\section{MATERIAL AND METHODS}

\section{Patients}

Twenty-four symptomatic patients (19 females and 5 males; from 13 to 67 years old - mean $=36.42$ years) were enrolled after clinical evaluation by physicians and dentists. All participants reporting at least one sign or symptom of temporomandibular disorder were included in this study, including pain, limited mouth opening, TMJ clicking, and crepitation. The images of patients who underwent surgical procedures or had inflammatory joint diseases, facial growth disturbances, facial bone trauma or fracture, hypoplasia, hyperplasia, or tumors in the mandible head region were excluded from the study. All individuals were well-informed regarding the objectives and procedures of the study, and officially consented to participate. Data on gender, age, anatomy, articular disc location, condyle anatomy, and articular eminence morphology were collected initially in a descriptive manner.

\section{Image acquisition}

MRI was carried out with a 1.5-Tesla apparatus (Signa 1.5 T; GE Healthcare, Little Chalfont, UK) using the same surface coil (20-cm diameter, double surface coil). The images were digitally processed in an independent workstation (EasyVision, Philips Medical Systems, Best, Netherlands); recorded in Digital Imaging and Communications in Medicine (DICOM) format; imported to an iMac computer (Mac OsX 10.6, Apple, Inc., Cupertino, USA) with Intel Core i5 2.5 GHz Processor, 4GB memory - 500GB, 21.5 inch screen, and $1920 \times 1080$ pixel resolution; and analyzed in the Osirix MD software (Apple Inc., version 3.9.4, 32 Bits - Pixmeo, Geneva, Switzerland).

Sagittal and coronal T1, T2, and proton density images of the TMJs were obtained with open mouth (openings of 10, 20, and $30 \mathrm{~mm}$ ), using a intraoral plastic device with a millimetric scale (GE Medical Systems $®$ ), and with closed mouth (maximum intercuspation), for a total of 33 TMJs (considering just joints diagnosed with disc displacement without reduction: posterior band positioned anterior to the condyle either at closed or maximum opening mouth positions). 


\section{Image evaluation}

All diagnoses were performed independently by two oral and maxillofacial radiologists, experienced in the interpretation of TMJ on MRI. In case of any disagreement in the diagnosis, the final diagnosis was made by consensus. The data from their reports were used in this study.

\section{Disc displacement without reduction}

All images evaluated were from patients diagnosed with disc displacement without reduction. Disc positions were analyzed in the coronal view, according to three situations: normal (the posterior band of the disc is centered in relation to the condyle and to the floor of the mandibular fossa); lateral displacement (the articular disc is displaced laterally in relation to the condyle); and medial displacement (the articular disc is displaced medially in relation to the condyle).

\section{Lateral pterygoid muscle}

The medial sections in both open and closed mouth positions were evaluated to determine the LPM insertion pattern. Insertion patterns were categorized into three groups: Type I - the superior head consists of two bundles, one attaching to the disc and the other to the condyle, while the inferior head reaches the condyle (Fig. 1); Type II - the superior head has one bundle reaching both disc and condyle, while the inferior head involves only the condyle (Fig. 2); Type III - the superior head has a single bundle attaching to the disc, while the inferior head inserts onto the condyle (Fig. 3). ${ }^{2}$ Ratings of the upper head of the LPM were performed with open-mouth parasagittal scans to better view the outstretched capsular structures and avoid interposition of the articular tubercle of the temporal bone.

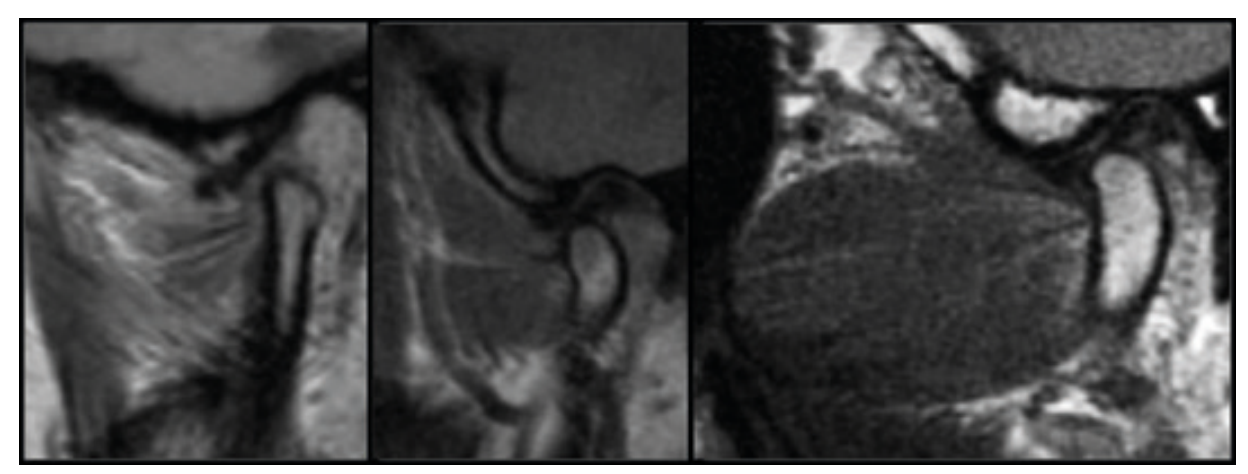

Figure 1 | MRI showing Type I: the superior head consists of two bundles, one attaching to the disc and the other to the condyle, while the inferior head reaches the condyle.

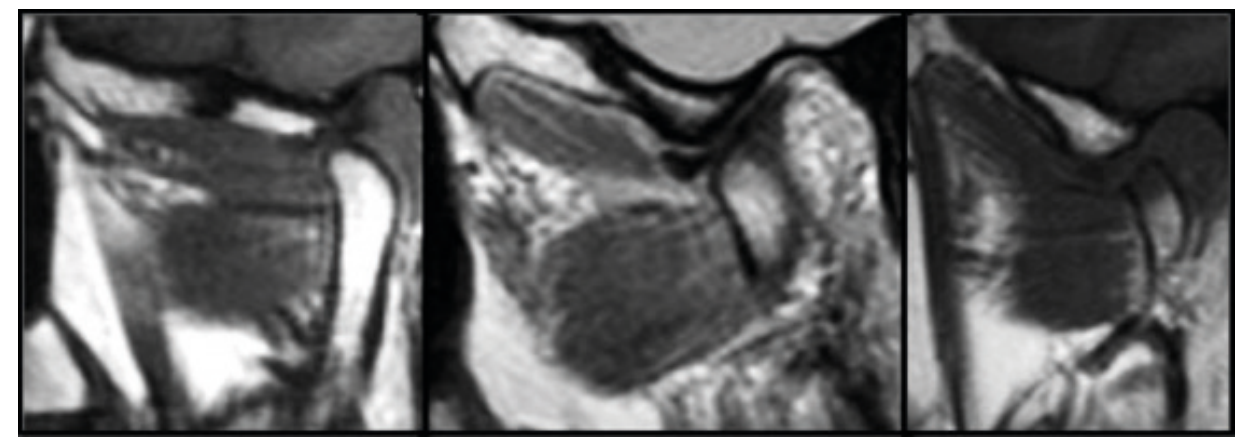

Figure 2 | MRI showing Type II: the superior head has one bundle reaching both disc and condyle, while the inferior head involves only the condyle. 


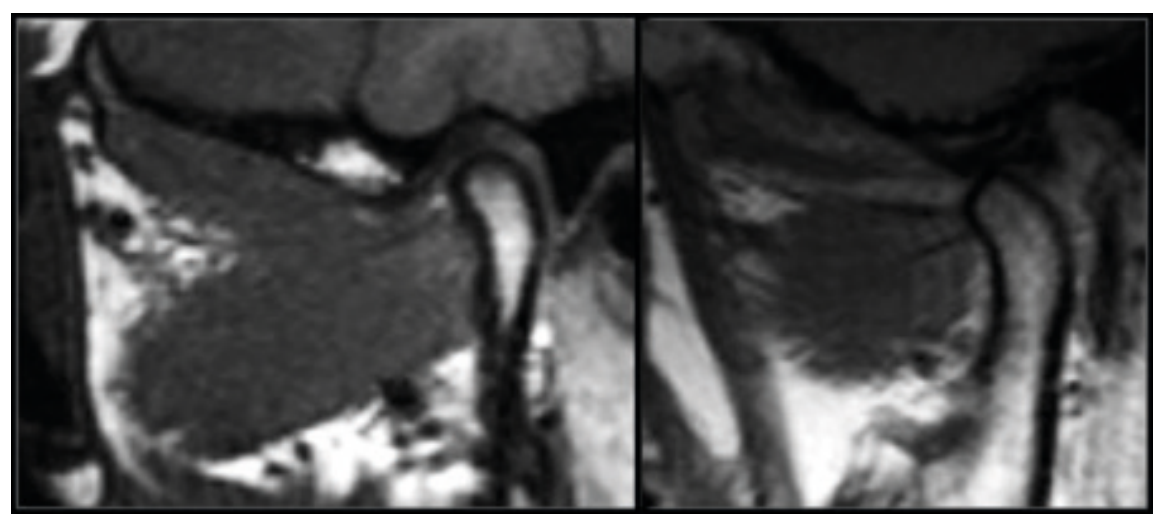

Figure 3 | MRI showing Type III: the superior head has a single bundle attaching to the disc, while the inferior head inserts onto the condyle.

\section{Morphologies}

Sagittal plane images were used to assess the anatomy of the articular eminence and the anatomy and position of the disc. The disc was classified as normal (biconcave), elongated, or folded; the articular eminence was classified as box, sigmoid, flattened, or deformed, according to Hirata et al.7 The condyle was assessed on coronal images. Condyle morphology was classified as convex, rounded, flattened, or angulated, according to Yale et al. ${ }^{8}$

\section{Joint effusion}

The presence or absence of joint effusion was evaluated by observing high signal intensity in the articular spaces on T2weighted images. The assessment was quantitative, because only the presence or absence of effusion was considered in the analysis.

\section{Data analysis}

Inferential analysis was conducted to confirm or refute the evidence found in the descriptive analysis. Chi-square test and Yates correction were used in the statistical analysis of the data, and the significance level adopted was 5\%. The following software were used: SPSS V17, Minitab 16, and Excel Office 2010. This study was approved by the institutional ethics committee (protocol 13/11, CAAE 0015.0.017.000-11).

\section{RESULTS}

Table 1 shows the frequency distribution of each item studied: presence of joint effusion; form and position of the articular disc (sagittal and coronal); form of condyle and articular eminence; mobility and insertion patterns of the lateral pterygoid muscle.

Table 2 shows the relation of TMJ mobility with condyle, articular eminence, and disc forms. Of the 29 joints with hypomobility, 11 had a flattened condyle form, 11 had a flattened articular eminence form, and 14 discs were folded. The statistical findings showed that TMJ mobility and insertion pattern were not associated with the qualitative variables, i.e., they were statistically independent variables. We highlight that the relations between TMJ mobility and disc form yielded a statistically significant result on the Chi-square test. However, since there were less than five cases with significant association, we applied Yates correction, which rendered a non-significant result.

Similarly, no association was found between insertion pattern and sideways disc position, disc form, and condyle form (Table 3). Even the results were not significant. There can be a relationship connecting 
TMJ mobility with a normal disc form (100\%); TMJ hypomobility with a folded disc form (48\%); and TMJ hypermobility with an elongated disc form (100\%).

Table 4 presents comparisons between joint effusion; disc form; condyle form; articular eminence form; TMJ mobility; and pterygoid muscle insertion pattern. All cases with joint effusion were related to hypomobility (100\%).

Table 5 describes the main results obtained in this research.

Table 1 | Disc displacement without reduction related to the frequency distribution of disc form and position, condyle and articular eminence form, presence of effusion, mobility, and insertion pattern.

\begin{tabular}{|c|c|c|}
\hline & Frequency distribution $(n=33)$ & $\%$ \\
\hline \multicolumn{3}{|l|}{ Effusion } \\
\hline Yes & 11 & $33.3 \%$ \\
\hline No & 22 & $66.7 \%$ \\
\hline \multicolumn{3}{|l|}{ Disc form } \\
\hline Normal & 8 & $24.3 \%$ \\
\hline Elongated & 12 & $36.3 \%$ \\
\hline Folded & 13 & $39.4 \%$ \\
\hline \multicolumn{3}{|c|}{ Sideways disc position } \\
\hline Normal & 23 & $69.7 \%$ \\
\hline Medial & 7 & $21.2 \%$ \\
\hline Lateral & 3 & $9.1 \%$ \\
\hline \multicolumn{3}{|c|}{ Condyle form } \\
\hline Flattened & 13 & $39.4 \%$ \\
\hline Convex & 6 & $18.2 \%$ \\
\hline Rounded & 8 & $24.3 \%$ \\
\hline Angulated & 6 & $18.2 \%$ \\
\hline \multicolumn{3}{|c|}{ Articular eminence form } \\
\hline Box & 7 & $21.2 \%$ \\
\hline Flattened & 14 & $42.4 \%$ \\
\hline Sigmoid & 8 & $24.2 \%$ \\
\hline Deformed & 4 & $12.2 \%$ \\
\hline \multicolumn{3}{|l|}{ Mobility } \\
\hline Normal & 1 & $3.0 \%$ \\
\hline Hypo & 29 & $87.9 \%$ \\
\hline Hyper & 3 & $9.1 \%$ \\
\hline \multicolumn{3}{|c|}{ Insertion pattern } \\
\hline Type I & 6 & $18.2 \%$ \\
\hline Type II & 14 & $42.4 \%$ \\
\hline Type III & 13 & $39.4 \%$ \\
\hline
\end{tabular}


- Association between disc displacement without reduction and temporomandibular joint derangement observed on magnetic resonance imaging

Table 2 | Relation of TMJ mobility with condyle, articular eminence, and disc forms.

\begin{tabular}{|c|c|c|c|c|c|c|c|c|c|c|}
\hline \multirow{2}{*}{\multicolumn{2}{|c|}{ TMJ Mobility }} & \multicolumn{2}{|c|}{ Normal } & \multicolumn{2}{|c|}{ Нyро } & \multicolumn{2}{|c|}{ Hyper } & \multicolumn{2}{|c|}{ Total } & \multirow{2}{*}{ P-value } \\
\hline & & N & $\%$ & $\mathrm{~N}$ & $\%$ & $\mathrm{~N}$ & $\%$ & $\mathrm{~N}$ & $\%$ & \\
\hline \multirow{4}{*}{ Condyle form } & Flattened & 0 & $0 \%$ & 11 & $38 \%$ & 1 & $33 \%$ & 12 & $36 \%$ & \multirow{4}{*}{0.693} \\
\hline & Convex & 0 & $0 \%$ & 5 & $17 \%$ & 1 & $33 \%$ & 6 & $18 \%$ & \\
\hline & Rounded & 1 & $100 \%$ & 7 & $24 \%$ & 1 & $33 \%$ & 9 & $27 \%$ & \\
\hline & Angulated & 0 & $0 \%$ & 6 & $21 \%$ & 0 & $0 \%$ & 6 & $18 \%$ & \\
\hline \multirow{4}{*}{$\begin{array}{l}\text { Articular } \\
\text { eminence } \\
\text { form }\end{array}$} & Box & 0 & $0 \%$ & 7 & $24 \%$ & 0 & $0 \%$ & 7 & $21 \%$ & \multirow{4}{*}{0.784} \\
\hline & Flattened & 1 & $100 \%$ & 11 & $38 \%$ & 2 & $67 \%$ & 14 & $42 \%$ & \\
\hline & Sigmoid & 0 & $0 \%$ & 7 & $24 \%$ & 1 & $33 \%$ & 8 & $24 \%$ & \\
\hline & Deformed & 0 & $0 \%$ & 4 & $14 \%$ & 0 & $0 \%$ & 4 & $12 \%$ & \\
\hline \multirow{3}{*}{ Disc form } & Normal & 1 & $100 \%$ & 4 & $14 \%$ & 0 & $0 \%$ & 5 & $15 \%$ & \multirow{3}{*}{$0.617(\mathrm{Y})^{*}$} \\
\hline & Elongated & 0 & $0 \%$ & 11 & $38 \%$ & 3 & $100 \%$ & 14 & $42 \%$ & \\
\hline & Folded & 0 & $0 \%$ & 14 & $48 \%$ & 0 & $0 \%$ & 14 & $42 \%$ & \\
\hline \multicolumn{2}{|c|}{ Total } & 1 & $3 \%$ & 29 & $88 \%$ & 3 & $9 \%$ & 33 & $100 \%$ & \\
\hline
\end{tabular}

* Yates correction.

Table 3 | Association of insertion pattern with sideways disc position, disc form, and condyle form.

\begin{tabular}{|c|c|c|c|c|c|c|c|c|c|c|}
\hline \multicolumn{2}{|c|}{ Insertion pattern } & \multicolumn{2}{|c|}{ Type I } & \multicolumn{2}{|c|}{ Type II } & \multicolumn{2}{|c|}{ Type III } & \multicolumn{2}{|c|}{ Total } & P-value \\
\hline \multirow{3}{*}{$\begin{array}{l}\text { Sideways disc } \\
\text { position }\end{array}$} & Normal & 3 & $50 \%$ & 13 & $93 \%$ & 7 & $54 \%$ & 23 & $70 \%$ & \multirow{3}{*}{0.173} \\
\hline & Medial & 2 & $33 \%$ & 1 & $7 \%$ & 4 & $31 \%$ & 7 & $21 \%$ & \\
\hline & Lateral & 1 & $17 \%$ & 0 & $0 \%$ & 2 & $15 \%$ & 3 & $9 \%$ & \\
\hline \multirow{3}{*}{ Disc form } & Normal & 2 & $33 \%$ & 1 & $7 \%$ & 1 & $8 \%$ & 4 & $12 \%$ & \multirow{3}{*}{0.083} \\
\hline & Elongated & 2 & $33 \%$ & 9 & $64 \%$ & 3 & $23 \%$ & 14 & $42 \%$ & \\
\hline & Folded & 2 & $33 \%$ & 4 & $29 \%$ & 9 & $69 \%$ & 15 & $45 \%$ & \\
\hline \multirow{4}{*}{ Condyle form } & Flattened & 2 & $33 \%$ & 5 & $36 \%$ & 5 & $38 \%$ & 12 & $36 \%$ & \multirow{4}{*}{0.631} \\
\hline & Convex & 1 & $17 \%$ & 3 & $21 \%$ & 2 & $15 \%$ & 6 & $18 \%$ & \\
\hline & Rounded & 3 & $50 \%$ & 4 & $29 \%$ & 2 & $15 \%$ & 9 & $27 \%$ & \\
\hline & Angulated & 0 & $0 \%$ & 2 & $14 \%$ & 4 & $31 \%$ & 6 & $18 \%$ & \\
\hline \multicolumn{2}{|c|}{ Total } & 6 & $18 \%$ & 14 & $42 \%$ & 13 & $39 \%$ & 33 & $100 \%$ & \\
\hline
\end{tabular}


Table 4 || Comparisons between joint effusion; disc form; condyle form; articular eminence form; TMJ mobility; and pterygoid muscle insertion pattern.

\begin{tabular}{|c|c|c|}
\hline Joint effusion & $n$ & $\%$ \\
\hline \multicolumn{3}{|l|}{ Disc form } \\
\hline Normal & 3 & $27.3 \%$ \\
\hline Elongated & 4 & $36.3 \%$ \\
\hline Folded & 4 & $36.3 \%$ \\
\hline \multicolumn{3}{|l|}{ Condyle form } \\
\hline Convex & 1 & $9.1 \%$ \\
\hline Flattened & 4 & $36.3 \%$ \\
\hline Angulated & 2 & $18.2 \%$ \\
\hline Rounded & 4 & $36.3 \%$ \\
\hline \multicolumn{3}{|l|}{ Articular eminence form } \\
\hline Box & 4 & $36.3 \%$ \\
\hline Deformed & 2 & $18.2 \%$ \\
\hline Sigmoid & 1 & $9.1 \%$ \\
\hline Flattened & 4 & $36.3 \%$ \\
\hline \multicolumn{3}{|l|}{ TMJ Mobility } \\
\hline Normal & 0 & 0 \\
\hline Hypo & 11 & $100 \%$ \\
\hline Hyper & 0 & $0 \%$ \\
\hline \multicolumn{3}{|l|}{ Insertion pattern } \\
\hline Type I & 3 & $27.3 \%$ \\
\hline Type II & 3 & $27.3 \%$ \\
\hline Type III & 5 & $45.4 \%$ \\
\hline
\end{tabular}

Table 5 | Main results obtained in this research.

\begin{tabular}{l|l|c|c}
\multicolumn{1}{c|}{ Variable } & \multicolumn{1}{|c|}{ Category } & N & $\%$ \\
\hline Joint effusion & No & 22 & $66.7 \%$ \\
\hline Disc form & Folded & 13 & $39.4 \%$ \\
\hline Sideways disc position & Normal & 23 & $69.7 \%$ \\
\hline Condyle form & Flattened & 13 & $39.4 \%$ \\
\hline Articular eminence form & Flattened & 14 & $42.4 \%$ \\
\hline TMJ mobility & Hypo & 29 & $87.9 \%$ \\
\hline Insertion pattern & Type II & 14 & $42.4 \%$ \\
\hline
\end{tabular}




\section{DISCUSSION}

Several studies have described joint disc displacement in relation to different factors ${ }^{9,10}$. However, it is difficult to pinpoint any definite relationship. This approach does not consider any other hypothesis, such as biochemical changes, and they are not the purpose of this study. Thus, based on the status of the joint, as categorized by some authors, ${ }^{11}$ we tried to relate only the cases of disc displacement without reduction and with insertion of the lateral pterygoid muscle.

It is usually not enough to diagnose some conditions based only on the TMJ clinical examination. When analyzing joint disc changes, joint eminence, and joint effusion, a particular overestimation could occur, correlating with clinical symptoms. This study recognizes the presence of clinical symptomatology, although it reports changes in MRI. The most significant advantage of TMJ assessment by MRI is the ability to evaluate the integrity of the anatomic structures and the amount of synovial fluid, as well as the relation between soft and bone tissues. Therefore, MRI is considered the gold standard.9,10 The sagittal images used in this study were very helpful in diagnosing both TMJ internal derangements and LPM morphology.

Internal derangement can be described as an abnormal relation between the variables of articular disc, condyle, and articular eminence, and may lead to visible degenerative changes in the soft and bone tissues observed in imaging examinations.9,12 These alterations include articular disc displacement and morphologic changes in the articular disc, articular eminence, and condyle..$^{4-6}$ The type of LPM attachment may determine the tendency for TMJ disorders. ${ }^{13}$ Medial displacement has been found to result more frequently in a TMJ disorder than in lateral displacement caused by the attachment of the LPM to the medial portion of the disc at the pterygoid fossa. ${ }^{14,15}$ Moreover, no correlation has been found between the LPM attachment type and the presence or absence of disc displacement, disc degeneration, or articular surface degeneration. ${ }^{16,17}$ Similarly, our study has also failed to establish any correlation.

Disc displacement without reduction is more commonly associated with joint effusion than earlier stage disc displacement with reduction. ${ }^{11}$ These results could point to the chronic degenerative process that is associated with disc displacement without reduction being responsible for changes within the TMJ space, ultimately resulting in fluid accumulation. ${ }^{6}$ In our study, we evaluated only cases of disc displacement without reduction, and observed that only 33.3\% presented joint effusion.

In conclusion, this study did not find a statistically significant correlation between the three types of muscle attachment to disc displacement without reduction. Technological advance is evidently heading toward the improvement of imaging techniques that can enable better understanding of the TMJ. Thus, our findings have raised considerations that suggest what should be focused on further studies.

\section{REFERENCES}

1. Kuroda S, Tanimoto K, Izawa T, Fujihara S, Koolstra JH, Tanaka E. Biomechanical and biochemical characteristics of the mandibular condylar cartilage. Osteoarthritis Cartilage. 2009 Nov;17(11):1408-15. doi:10.1016/j.joca.2009.04.025.

2. Mazza D, Marini M, Impara L, Cassetta M, Scarpato P, Barchetti F, et al. Anatomic examination of the upper head of the lateral pterygoid muscle using magnetic resonance imaging and clinical data. J Craniofac Surg. 2009 Sep;20(5):1508-11. doi: 10.1097/SCS.obo13e3181bo9c32.

3. Kim HJ, Kwak HH, Hu KS, Park HD, Kang HC, Jung HS, et al. Topographic anatomy of the mandibular nerve branches distributed on the two heads of the lateral pterygoid. Int $\mathrm{J}$ Oral Maxillofac Surg. 2003 Aug;32(4):408-13.

4. Orlando B, Chiappe G, Landi N, Bosco M. Risk of temporomandibular joint effusion related to magnetic resonance imaging signs of disc displacement. Med Oral Patol Oral Cir Bucal. 2009 Apr 1;14(4):E188-93. 
5. Rudisch A, Innerhofer K, Bertram S, Emshoff R. Magnetic resonance imaging findings of internal derangement and effusion in patients with unilateral temporomandibular joint pain. Oral Surg Oral Med Oral Pathol Oral Radiol Endod. 2001 Nov;92(5):566-71.

6. Manfredini D, Basso D, Salmaso L, Guarda-Nardini L. Temporomandibular joint click sound and magnetic resonancedepicted disk position: which relationship? J Dent. 2008 Apr;36(4):256-6o. doi: 10.1016/j.jdent.2008.01.002.

7. Hirata FH, Guimarães AS, Oliveira JX, Moreira CR, Ferreira ET, Cavalcanti MG. Evaluation of TMJ articular eminence morphology and disc patterns in patients with disc displacement in MRI. Braz Oral Res. 2007 Jul-Sep;21(3):265-71.

8. Yale SH, Ceballos M, Kresnoff CS, Hauptfuehrer JD. Some observations on the classification of mandibular condyle types. Oral Surg Oral Med Oral Pathol. 1963 May;16:572-7.

9. Sener S, Akgänlü F. MRI characteristics of anterior disc displacement with and without reduction. Dentomaxillofac Radiol. 2004 Jul;33(4):245-52.

10. Roh HS, Kim W, Kim YK, Lee JY. Relationships between disk displacement, joint effusion, and degenerative changes of the TMJ in TMD patients based on MRI findings. J Craniomaxillofac Surg. 2012 Apr;40(3):283-6. doi:10.1016/j.jcms.2011.04.006.

11. Huh JK, Kim HG, Ko JY. Magnetic resonance imaging of temporomandibular joint synovial fluid collection and disk morphology. Oral Surg Oral Med Oral Pathol Oral Radiol Endod. 2003 Jun;95(6):665-71.
12. De Leeuw R, Boering G, Stegenga B, de Bont LG. TMJ articular disc position and configuration 30 years after initial diagnosis of internal derangement. J Oral Maxillofac Surg. 1995 Mar;53(3):234-41; discussion 241-2.

13. Antonopoulou M, Iatrou I, Paraschos A, Anagnostopoulou S. Variations of the attachment of the superior head of human lateral pterygoid muscle. J Craniomaxillofac Surg. 2013 Sep;41(6):e91-7. doi: 10.1016/j.jcms.2012.11.021.

14. Taşkaya-Yilmaz N, Oğütcen-Toller M. Magnetic resonance imaging evaluation of temporomandibular joint disc deformities in relation to type of disc displacement. J Oral Maxillofac Surg. 2001 Aug;59(8):860-5; discussion 865-6.

15. Schmitter M, Kress B, Ludwig C, Koob A, Gabbert O, Rammelsberg P. Temporomandibular joint disk position assessed at coronal MR imaging in asymptomatic volunteers. Radiology. 2005 Aug;236(2):559-64.

16. Dergin G, Kilic C, Gozneli R, Yildirim D, Garip H, Moroglu S. Evaluating the correlation between the lateral pterygoid muscle attachment type and internal derangement of the temporomandibular joint with an emphasis on MR imaging findings. J Craniomaxillofac Surg. 2012 Jul;4O(5):459-63. doi: 10.1016/j.jcms.2011.08.002.

17. Taskaya-Yilmaz N, Ceylan G, Incesu L, Muglali M. A possible etiology of the internal derangement of the temporomandibular joint based on the MRI observations of the lateral pterygoid muscle. Surg Radiol Anat. 2005 Mar;27(1):19-24. 